\title{
Law Enforcement in Banking Criminal Act Involving Insiders
}

\author{
Ridwan Arifin \\ Faculty of Law, Universitas Negeri Semarang \\ ridwan.arifin@mail.unnes.ac.id
}

\begin{abstract}
The rise of news in the mass media related to burglary cases of bank customer funds further raises public awareness of the vulnerability of the banking sector used as a and as the target of crime against the bank. On the other hand, the awareness is intended to further convince each party that the bank in conducting its business activities must be managed and managed by parties who have integrity and good competence. The purpose of this research is to: (1) analyze and describe the implementation of the rule of law in handling banking criminal case involving insider; and (2) to know and analyze government efforts both preventive and repressive in handling banking crime cases in Indonesia, especially in cases involving insiders. This paper used normative method with statutes approach. This paper compare the laws and regulations concerning to banking crime and the law enforcement. The results showed that the implementation of law in handling banking crime cases in addition to using Law No. 10 of 1998 on Amendment to Law No. 7 of 1992 concerning to Banking (Banking Act), also used several provisions of article in the Criminal Code (KUHP) and Law No. 20 Year 2011 jo. Law No. 31 Year 1999 on the Eradication of Corruption. The role of Bank Indonesia in the enforcement of law in the form of investigation and/or forensic examination of banking crime that occurred in a bank which then the result of investigation is reported to law enforcement in accordance with applicable Criminal Procedure Code. The
\end{abstract}


weakness of internal controls is the cause of the ineffectiveness of handling of banking crime cases, especially those involving insiders, a memorandum of understanding between Bank Indonesia, the Police and the Attorney Office is only a moral obligation, should be more binding so that it can become one of the more powerful law enforcement tools.

Keywords: Banking Crime, Law Enforcement, Insider, Criminal Act, Indonesia

\section{A. Introduction}

The development of crime in various countries in the midst of technological developments to make law and law enforcement itself must continue to grow. Various crimes, including in Indonesia, have developed not only on a national but also international scale. one of the most widespread crimes is banking crime. The rise of news in the mass media related to burglary cases of bank customer funds further raises public awareness of the vulnerability of the banking sector used as a means (crimes through the bank) and as the target of crime against the bank. On the other hand, the awareness is intended to further convince each party that the bank in conducting its business activities must be managed and managed by parties who have integrity and good competence.

The handling of cases occurring in the banking sector should be handled carefully by prioritizing the interests of maintaining and securing public funds available to the bank, the viability of the bank as an institution, and the banking system as a whole, without prejudice to speed and truth litigation. Careful preparation is necessary because the banking sector as a trust institution has a high degree of sensitivity to issues or rumors. Trust is an important aspect (influential) because the banking business performs a financial intermediary function that brings a surplus unit of fund with a deficit unit of fund.

Handling cases that occur in the banking sector in addition to reducing the level of greater losses, is also intended to maintain public confidence. In cases where the banking industry is not handled 
carefully it is feared that it can develop into a systemic problem. That is, distrust of banks or banks will manifest in the form of withdrawal of funds on a large scale in almost the same time. Through the financial sector is the center of the system in an economy so that the failure of the financial sector can weaken the performance of the entire system in the economy.

In fact, the important role of banks in building the country's economy and finances lies not only in how much public confidence in banks, but also how far banks have their partners and business guarantor. The existence of banking as one financial institution which is basically a financial intermediary, where its main function as collecting and channeling of public funds, is the spearhead of the financial sector whose priority is very important. The importance or urgency of the bank, one of them because the banking institution is potentially vulnerable to acts that can be categorized as a violation of law whose access not only befall the relevant banks but also other banks, customers, and government or state (Sholehuddin, 1997: 2).

The role of the banking sector in promoting national economic growth is also manifested in its main function as an intermediary between debtors and creditors. In addition, the bank becomes a bridge for financing the real sector in improving the business climate and investment climate in the framework of job creation. ${ }^{1}$ The increasing flow of money in the country makes the banking sector as the most strategic sector in trade and development. Banks are closely related to the provision of capital for business or trade, so that the wheels of the economy can continue to run. ${ }^{2}$

Not only economic activities, banking activities also support the achievement of prosperous life, as the development goal in Indonesia to build a complete Indonesian people, which includes not only economic development but also all aspects of human life. The support

1 Wiji Nurhayat, "Ini Arti Penting Perbankan di Indonesia Bagi Pemerintah", detikfinance edition 6 January 2014, Online News, http://finance.detik. $\mathrm{com} / \mathrm{read} / 2014 / 01 / 06 / 110215 / 2459047 / 5 /$ ini-arti-penting-perbankandi-indonesia-bagi-pemerintah, Accessed 2 December 2017

2 Abdul Wahab Bangkona, om Wiji Nurhayat, Ibid. 
of the banking world for the purpose asserted in the Guidelines of State Policy (GBHN) can be seen from the basics of consideration of each published law, such as in Act Number 23 of 1999 concerning Bank Indonesia, which explicitly stated in its consideration that this law, is to maintain national sustainability in order to create a just and prosperous Indonesian society based on Pancasila and the 1945 Constitution of the State of the Republic of Indonesia. ${ }^{3}$

In order to carry out these objectives, banks must be supported by adequate regulation to ensure all their activities, but in the implementation of banking often raises various legal issues, be it civil and criminal fields. In fact, regulation related to banking has started since the enactment of Law Number 14 Year 1967 concerning Banking Principles which is then revoked and Act Number 7 of 1992 concerning Banking and subsequently amended again with Law Number 10 Year 1998 regarding the Amendment Act Number 7 of 1992 concerning Banking, provides sufficient space in law enforcement in the banking sector, especially in banking crimes that are rampant in Indonesia.

On 2011 at least nine cases of bank break-ins in various banking industries, such as burglary Bank Rakyat Indonesia (BRI) Tamini Square cash, the disbursement of deposits and burglary of Bank Mandiri customers, to the investment fraud conspiracy for personal gain. ${ }^{4}$ The crime mode is not only due to fraud but also the weak

3 Chainur Arrasjid, Hukum Pidana Perbankan, Jakarta, Sinar Grafika, 2011, p. 86-88.

4 Data Strategic Indonesia through Criminal Investigation Agency Police Headquarters: (1) Burglary Office of Bank Rakyat Indonesia (BRI) Tamini Square. Involving the office supervisor is assisted by four suspects from outside the bank. The modus is, opening an account on behalf of a suspect outside the bank. The money was transferred to the account for 6 million US dollars. Then the money exchanged with black dollars (US dollar fake black) to 60 million US dollars. (2) Provision of credit with documents and fictitious guarantee at Bank Internasional Indonesia (BII) on January 31, 2011, total loss of Rp 3.6 billion. (3) Withdrawal of deposits and escaping the savings of Bank Mandiri customers, with a loss of Rp 18 billion. (4) Bank Negara Indonesia (BNI) Branch Margonda Depok. Suspect a representative of the branch BNI leadership. The mode, the suspect sent false telex news containing orders to move the credit decision slip by opening 
internal control of the bank against its human resources. ${ }^{5}$

During 2012, Bank Indonesia received reports of at least 1009 cases of electronic payment transactions fraud, and its total loss reached Rp.2.37 billion. ${ }^{6}$ While in 2013, Bank Indonesia, as a banking regulator, has investigated allegations of Banking Crime as many as 62 cases and the number of cases reported to Law Enforcement reached 35 cases consisting of 14 cases from Commercial Bank and 21 cases from BPR. ${ }^{7}$

Banking crime continues to experience the development of mode and form, for example, bank burglary. Bank break-ins have

a working capital loan account. (5) Withdrawal of deposits of Rp 6 billion from customers by BPR management without the knowledge of the owner in BPR Pundi Artha Sejahtera, Bekasi, West Java. At maturity of the deposit there is no fund. (6) On March 9 happened to Bank Danamon. His mode of head teller Bank Danamon Branch Menara Bank Danamon attracted repeat customer cash amounting to Rp 1.9 billion and 110,000 US dollars. (7) Embezzlement of customer funds made by Head of Operations of Panin Bank of Metro Sunter Branch by channeling funds into personal account, bank loss Rp 2.5 billion. (8) The burglary of Citibank Landmark priority customers worth Rp 16.63 billion, made the Senior Relationship Manager (RM) of the bank. Inong Malinda Dee, as RM, withdraws customers' funds without the owner's knowledge through the empty withdrawal slip already signed by the customer. (9) The investment fraud conspiracy worth Rp 111 billion for personal gain. See Nina Dwiantika, "Inilah 9 Kasus Kejahatan Perbankan”, Online News, edition 3 May 2011, retrieved from http:/ / bisniskeuangan.kompas.com/read/2011/05/03/09441743/Inilah.9.Kasus. Kejahatan.Perbankan, Accessed on 2 December 2017

5 Ibid.

6 Dion Bistara \& Grace Dwitya Amianti, "Indonesia Still Struggling with Electronic Fraud: Bank Indonesia”, Online News, edition 6 July 2012, retrieved from http://thejakartaglobe.beritasatu.com/archive/ indonesiastill-struggling-with-electronic-fraud-bi/, Accessed on 2 December 2017, 10.00

7 These cases occurred in 35 bank offices, consisting of 19 cases in 14 Commercial Bank offices, and 43 cases from 21 BPR offices. While the process of follow-up investigation results including carry over from the previous period there are some cases. For example, the number of cases discussed in the Banking Crime Coordination Forum reached 63 cases, consisting of 24 cases from Commercial Banks and 39 cases from BPR. See Nina Dwiantika, "2013, BI Investigasi 62 Kasus Tindak Pidana Bank", berita online, edition 11 March2014, retrieved from http:// keuangan.kontan.co.id/news/2013-biinvestigasi-62-kasus-tindak-pidana-bank, Accessed on 2 December 2017 


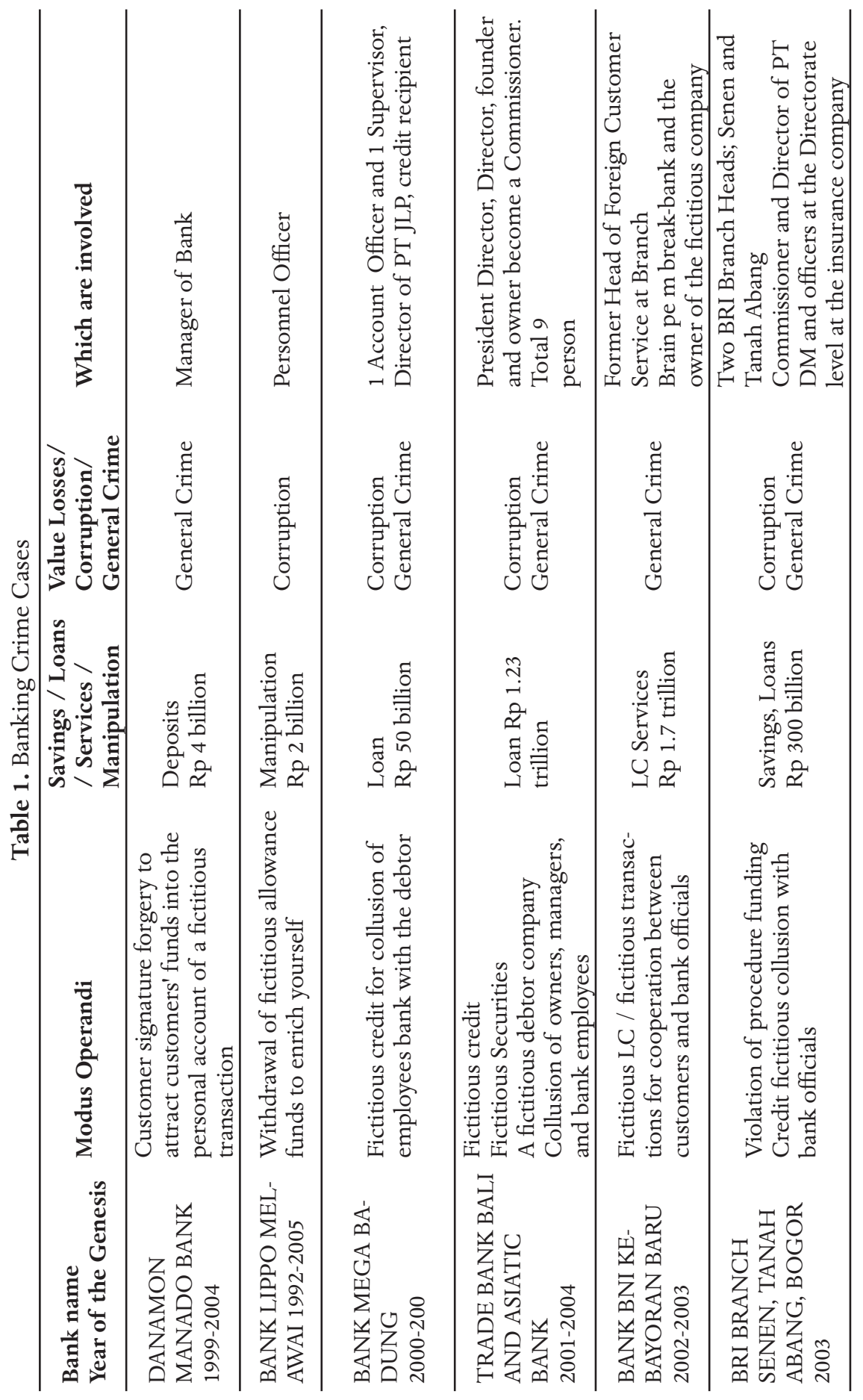


shifted in an increasingly sophisticated fashion according to technological developments and the complexity of financial transactions. The level of bank security is at stake when the frequency and scale of break-ins are getting bigger. Corporate fraud, embezzlement and corruption (corporate corruption) is a serious threat to the financial system. ${ }^{8}$ Some cases of crime and modus operandi can be seen from Table $1 .^{9}$

The data in the table showed that the potential loss of society on Banking Crime in Indonesia is very large. Not only that, Banking Crime in many cases, making banks unhealthy and unable to grow significantly. In fact, without a healthy and growing banking economy cannot be built, especially in the current era of globalization and market economy. Only the health of the bank can perform its functions. ${ }^{10}$

It is not easy to track crime activities in banking that are generally categorized into white collar crime. Hazel Croall asserted the inability to know early the occurrence of irregularities that are usually done in private by important officials who are authorized to make decisions in the environment of the bank concerned. ${ }^{11}$ Without denying the existence of the judiciary, banking practice requires the settlement of banking cases handled professionally, ensuring economic stability and trust in society and banking. Banking cases that are dealt with in a rambling, intense publication and an independent judiciary will undermine the banking reputation. ${ }^{12}$

Ineffective law enforcement may trigger widespread banking crime. There is often controversy in the handling of banking crimes

8 Anti-Corruption Clearing House KPK "Modus Korupsi Sektor Perbankan," Online Document, http://acch.kpk.go.id/documents/10157/27925/Modus_Korupsi_Sektor_Perbankan.pdf, p.18.

9 Ibid, pp. 45-47.

10 Adrian Sutedi, Hukum Perbankan: Suatu Tinjauan Pencucian Uang, Merger, Likuiditas, dan Kepailitan, Jakarta, Sinar Grafika, 2007, p. vi.

11 Hazel Croall stated that in ability of victims to detect offences is of course the mayor reason why so much white collar crime in unreported. Baharudin Lopa, Kejahatan Korupsi dan Penegakan Hukum, Jakarta, Kompas Gramedia, 2001, p. 37.

12 Adrian Sutedi, Op.Cit., p. vii. 
by the judge's free judgment of defendants who are indicated as criminals, such as the free judgment of defendants Rudi Ramli and Djoko S. Djandra in the case of Bank Bali which has caused great financial losses to the state. Therefore, there is a tendency of indecisiveness in the application of criminal provisions, due to the unclear provisions regulating such acts in existing criminal provisions, so as to be used for non-imposition of criminal sanctions. ${ }^{13}$

Law enforcement in banking crime becomes very important and greatly affects economic growth and prevents systemic failures in the banking sector. Continued development of the types of crimes that belong to the banking crime make the existing law enforcement must also be adequate. In addition, the role of law is very important in the economic field, namely by its ability to influence the degree of certainty in human relationships within society. ${ }^{14}$ Therefore, to the phenomenon of banking crimes were rampant and linked to the strategic role of the banking sector within the economic development needed steps are the evaluation and improvement into the future for banking crimes can be minimized so that the banking sector, which in essence is a trust business can still maintained its integrity in society.

In order to know comprehensively about the law enforcement of banking crime in Indonesia, especially banking crime involving insiders, this paper was highlighted to main issues that would be examined, first is how to implement the law in handling criminal cases involving bank insiders Indonesia, and second is what is the effort provided by government against banking crime involving insiders in Indonesia. These two issues was very important, because, empirically, banking crimes through fraud, burglary and looting often occur in Indonesia. Almost every year it happens, both the big banks and small banks, either by parties in the bank or outside parties, whether

13 Ferizal, "Kebijakan Hukum Pidana dalam Penanggulangan Tindak Pidana Bidang Perbankan”, Thesis, Master of Laws, Postgraduate Program Faculty of Law, Universitas Diponegoro, Semarang, 2001, p. 10

14 Satjipto Rahardjo, Hukum dan Masyarakat, Bandung, Angkasa, 1984, p. 144. 
done by the owners of banks and bank employees. ${ }^{15}$ The crime activity is said to be a white-collar crime that can cause a large scale ${ }^{16}$ and involves many parties within it. In addition to burglary and embezzlement of customer funds, other crimes such as fraud and crime related to bank secrets are also common and involve insiders or bank employees concerned.

\section{B. Implementation of Law Enforcement on Baking Crime Involving Insiders Case: An Indonesian Criminal Law Code and Banking Act Approach}

\section{Banking Crime in the Context Banking Law}

According to Law Number 10 of 1998 concerning Amendment to Act Number 7 of 1992 concerning Banking, Article 1 point (1) states that banking is anything that concerns the bank, including the institutional, business activities, and the way and process in carry out its business activities.

Meanwhile, regarding the definition of the bank itself Law No. Article 1 number (2) stated that Bank is a business entity that collects funds from the public in the form of savings and distributes it to the community in the form of credit and / or other forms in order to improve the living standard of the people. A more technical understanding can be explained in the Statement of Financial Accounting Standards (PSAK) Number 31, where the bank is said to be a financial institution that acts as a financial intermediary between parties with excess funds and parties requiring funds, as well as a functioning institution improving payment traffic. ${ }^{17}$

Crime in the banking sector is a criminal act that makes the bank as a means (crime against the bank). ${ }^{18}$ Criminal acts in the banking

15 Anti-Corruption Clearing House KPK, op.cit., p. 55.

16 Ibid., p. 57.

17 Statement of Financial Accounting Standards (PSAK) No. 31 of the Indonesian Institute of Accountants, 1994 (Pernyataan Standar Akuntansi Keuangan (PSAK) Nomor 31 Ikatan Akuntan Indonesia, 1994), hereinafter referred as PSAK 31/ 1994

18 Hermansyah, Hukum Perbankan Indonesia, Kencana, Jakarta, 2006, p. 149 
sector are all kinds of unlawful acts related to activities in running a bank business, whether bank as target or bank as a means. While banking crime is a crime committed by the bank, banking crime will be prosecuted through criminal provisions regulated in banking law, although the crime in the banking sector is dealt with through laws outside the banking law. ${ }^{19}$

Law No. 10 of 1998 on Banking does not formulate the definition of banking crime. This law only classifies several acts that belong to crime and as offenses. Use of the term Banking Crime and Criminal Acts in the Field of Banking there has been no emptiness opinion. Judging from the juridical side, none of the laws and regulations had provided insight into banking crime and criminal offenses in the banking sector. ${ }^{20}$

National Legal Development Board (BPHN), Ministry of Justice provides different understanding for both banking crime and criminal acts in banking, that is ${ }^{21}$ :

a. Banking crimes are:

i. Any act that violates the laws and regulations as stipulated in Law no. 7 of 1992 concerning Banking as amended by Act

19 Edi Setiadi, Hukum Pidana Ekonomi, Graha Ilmu, Yogyakarta, 2010, pp. 139141

20 BPHN, 1992, "Masalah-Masalah Hukum Kejahatan Perbankan”, Research Report, BPHN Departemen Kehakiman, Jakarta, p. 68. The term of criminal offenses in banking is contained in Article 2 paragraph (1) sub-paragraph g of Law No. 8 of 2010 on the Prevention and Eradication of Money Laundering Act, but in the Act there is no definition or understanding of crime in the field of banking.

21 Ibid., Compared with Marulak Pardede, Hukum Pidana Bank, Pustaka Sinar Harapan, Jakarta, 1995, p. 14, which suggests that the fundamentally basic differences in the understanding of criminal offenses in banking and banking crime are:

a. Banking Crime (Tindak Pidana Perbankan, Tipibank), is any action that violates the provisions as regulated in Law no. 7 of 1992 concerning Banking as amended by Act no. 10 of 1998 (Banking Act).

b. Criminal acts in the banking sector are any actions that violate the provisions as regulated in Law No. 7 of 1992 concerning Banking, Criminal Code, and Special Criminal Law Regulations, such as Law No. 3 of 1971 on Corruption Act, Law No.. 11 PNPS of 1963 on Subversion, and Law No. 7 Drt 1955 on Economic Crime. 
No. 10 of 1998 (Banking Act). ${ }^{22}$

ii. Criminal acts committed in carrying out its functions and business as a bank under the Banking Act. ${ }^{23}$

b. Criminal acts in banking are:

i. All types of unlawful acts related to activities in running a bank business, whether the bank as a target or as a means. ${ }^{24}$

ii. Criminal acts which include not only violations of the Law on Banking, but also include criminal acts of fraud, embezzlement, fraud and other criminal offenses as far as banking institutions are concerned..$^{25}$

There are two popular terms in banking crime, namely the term Crime Banking and the term of Criminal Acts in the Field of Banking. ${ }^{26}$ The first term implies that the offense is solely perpetrated by a bank or internal party within the bank, which may consist of an officer, officer, party affiliated with a bank including a shareholder of a bank. Meanwhile, the second term appears to be more neutral and broad because it can include offenses committed by outsiders and banks or both. In other words, the term criminal offense in the banking sector is intended to accommodate all kinds of unlawful acts related to activities in running a bank business.

In addition to these two terms, there are also those that distinguish bank related criminal offenses including criminal acts which make the bank as a means of crime through the bank and the bank as the target of crime against the bank. ${ }^{27}$ The applicable Banking Act does not govern the limits or definitions of what constitutes criminal law

22 BPHN, Departemen Kehakiman, ... op.cit., p. 18

23 Ibid, p. 8. H.A.K. Moch. Anwar, Tindak Pidana di Bidang Perbankan, Alumni, Bandung, 1986, p. 44, called a criminal offense in the banking sector as a banking crime to accommodate all kinds of unlawful acts related to activities in running a bank business. The term banking crime is used because there are no specific Criminal Code rules designed to threaten and punish the acts mentioned above. In addition, banking crimes have broad meaning, because it can mean the bank as a victim or bank as the perpetrator.

24 BPHN, loc.cit

25 Ibid., pp. 12-13.

26 Edi Setiadi, loc.cit.

27 Hermansyah, loc.cit. 
and crime. The Banking Act only stipulates thirteen kinds of criminal acts as regulated from Articles 46 through 50A can be grouped as follows:

1) Criminal acts relating to licensing (Article 46);

2) Criminal acts relating to bank secrecy (Article 47 paragraph (1), Article 47 paragraph (2), Article 47A);

3) Criminal acts relating to supervision and coaching (Article 48 paragraph (1), Article 48 paragraph (2)); and

4) Criminal acts relating to the business of the bank (Article 49 paragraph (1) a, b, and c, Article 49 paragraph (2) a and b);

5) Criminal acts relate to affiliated parties (Article 50); and

6) The criminal act relates to the owner / shareholder of the bank (Article 50A).

The scope of criminal offenses in banking as stipulated in Article 46 through Article 50A of the Banking Law is to use the bank as a target in criminal acts committed by internal parties (including affiliated parties). Bank Indonesia data from 2004-2009 shows that the results of investigations of banking violations reached 1,139 cases. The number of banks (commercial banks and rural banks) investigated reached 589 banks. The number of cases that have been investigated has reached 1,026, although there are still 292 cases that have not been followed up by the investigation for several reasons, for example not containing criminal elements, already handled by law enforcement, being the authority of other agencies (such as taxation), or expiring. ${ }^{28}$

The types of violations of banking regulations performed include credit swaps , fictitious debtors, fictitious loans, trade finance , engineering to avoid 30\% maximum credit limit , $17 \%$ funding, reporting/bookkeeping/recording engineering $17 \%$, do not register $11 \%$, fictitious cost and mark-up cost of $7 \%$, embezzlement of $5 \%$, and others (asset pickup, funds transfer, taxation, unlicensed fundraising, capital, foreign exchange transactions, abuse of authority, cyber fraud, bank practices in banks by $13 \% .^{29}$

28 Bank Indonesia official website, www.bi.go.id

29 With regard to the maximum crediting limit (Batas Maksimum Pemberian 
This study focuses on criminal offenses related to the bank's business as referred to in Article 49 paragraph (1), considering that many cases of customer fund burglary incurred and involving insider persons without that mode of operation of burglary of client funds can be categorized as acts punishment related to the business of a bank as referred to in Article 49 paragraph (1) of the Banking Act.

Article 49 paragraph (1) of the Banking Act basically regulates the threat of criminal sanctions for members of the Board of Commissioners, Board of Directors, or bank employees who deliberately:

1) Create or cause false records in the books or in reports, nor in documents or reports of business activities, transaction reports or bank accounts;

2) Eliminates or excludes or causes non-entry of records in the books or in reports, nor in documents or reports of business activities, transactions or accounts of a bank;

3) Changing, obscuring, hiding, deleting, or omitting any record keeping in the books or in reports, nor in documents or reports of business activities, transactions or accounts of a bank, or intentionally altering, obscuring, removing, harboring or destroying the accounting records.

When looking at the formulation of Article 49 paragraph (1) of the Banking Act appears that crime related to the bank's business can basically occur in all business activities of the bank, both in order to fund (funding), disbursement of funds (lending), or in activities business of other banks.

In the case of embezzlement, it appears that the role of the involvement of the bank (insider) become the dominant factor of the crime of banking, in addition to their negligence / inadvertence of the customer, as well as the lack of the functioning of the internal control of the bank. There are some disadvantages of in-tern control and weakness implementation of standard operating proce-

Kredit, BPMK), hereinafter called as BPMK, many cases also involve bank employees or insiders, such as the administration of authority and so on. Ibid. 
dure (SOP) that is:

1) Do not check and recheck the handling of transactions;

2) Less of supervision by supervisors against subordinates;

3) Less of the tightening of internal control system to priority banking operational activities $=$, which from the side of privacy has the advantage of service as well as having a vulnerability knot susceptibility by bank officials.

Meanwhile, the element of negligence and lack of customer care is reflected in vulnerable practices such as:

1) The priority banking customers who wish to be served only by customer service that has long been recognized and trusted by the customer;

2) Customer entrusts the blank form (transfer form/transfer/cash withdrawal) that has been signed to the bank officer;

3) Giving password ATM Personal Identity Number (PIN) to the bank officer.

Practices that are not prudent create an opportunity for the bank officers by conducting the transaction to obtain financial benefits unlawfully.

The combination of insider involvement in the bank plus customer negligence and negligence, as well as the disadvantages of implementing standard operating procedures (SOPs) created several cases of bank customers' break-ins. Some examples of such cases include:

1) The burglary at the cash office of Bank $X$ around USD6 million committed by the bank's cash office supervisor in collaboration with parties outside of the bank;

2) Withdrawal of fund deposits and the burglary at the branch office one state-owned bank with total losses of about Rp.18 billion allegedly involving bank officials concerned;

3) Customer disbursement by the BPR Y board in West Java, which allegedly involves the President Director of BPR, the main commissioner and the commissioner as well as parties from outside the bank;

4) Case of burglary customer deposits funds amounting Rp.16,63 billion in one of the foreign banks conducted by the Relationship 
Manager of the bank;

5) The burglary (the regional government and national private company) at the Bank $Z$ in Bekasi allegedly committed by the leader of the bank's branch office in collaboration with parties outside the banks (allegedly involving the leadership of the company/local government owners of the funds).

According to Law Number 10 of 1998 concerning Amendment to Act Number 7 of 1992 concerning Banking, there are thirteen (13) kinds of criminal offenses in the banking sector. Thirteen kinds of criminal acts in the banking sector are grouped into 5 main groups, namely:

a. Criminal acts related to licensing

Crime in the banking sector related to licensing is a criminal act related to the license of establishment of a bank as a financial institution. Any person who wants to establish a bank must comply with the terms or conditions contained in the law. Criminal acts included in the types of criminal offenses relating to licensing are contained in Article 46 of Act Number 7 of 1992 concerning the Principles of Banking, as amended by Act Number 10 of 1998 concerning Amendment to Act Number 7 of 1992 concerning Banking, which stated that:

Paragraph (1): "Anyone who collects funds from the public in the form of deposits in the form of demand deposits, time deposits, certificates of deposit, savings, and / or other forms similar to those without the business license of the Minister as referred to in Article 16 and Article 17, with a maximum imprisonment of 15 (fifteen) years and a maximum fine of Rp. 10.000.000.000, - (ten billion rupiah) and at most Rp. 200,000,000,000, - (two hundred billion rupiah)."

Paragraph (2): "In the event that the activities referred to in paragraph (1) are conducted by a limited legal entity, union, foundation or cooperative, the prosecution of such bodies is performed either against those who give the order to do the act or act as a leader in the act or against both."

b. Crime related to bank secrets

In Act Number 7 of 1992 concerning Banking Principles, as amended by Act Number 10 of 1998 concerning Amendment to 
Act Number 7 of 1992 concerning Banking, it is stated that the criminal acts which belong to the types of criminal offenses related to bank secrets, are contained in Article 47 paragraph (1), Article 47 paragraph (2), and Article 47A which stated that:

Paragraph (1): "Anyone without a written order or permission from the Chairman of Bank Indonesia as referred to in Article 41, Article $41 \mathrm{~A}$, Article 42 , intentionally compels the bank or affiliated party to provide the information referred to in 2 (two) years and not later than 4 (four) years and a fine of at least Rp. 10.000.000.000, - (ten billion rupiah) and at most Rp. 200,000,000,000, - (two hundred billion rupiah)."

Paragraph (2): "A member of the board of commissioners, board of directors, employee of a bank or other affiliated party deliberately providing information which shall be concealed under Article 40 shall be punishable by imprisonment of at least 2 (two) years and a maximum of 4 (four) years and a fine of at least Rp. 4.000.000.000, - (four billion rupiah) and at most Rp. 8,000,000,000, - (eight billion rupiah)."

Article 47A: "A member of the board of commissioners, board of directors, or bank clerk who intentionally fails to provide information which must be fulfilled as referred to in Article $42 \mathrm{~A}$ and Article 44A shall be punishable by imprisonment of at least 2 (two) years and no later than 7 (seven) years and a fine of at least Rp. 4.000.000.000, (four billion rupiah) and at most Rp.15.000.000.000, - (fifteen billion rupiah)."

Against criminal offenses relating to bank secrets, there are exceptions to the extent that the party committing the secret crime of the excluded bank is not punished, namely:

1) Opening bank secrets due to taxation interests (Article 41 paragraph (1))

2) The opening of bank secrets due to the interests of settlement of state receivables (Article 41A)

3) The opening of bank secrets due to the interests of the judiciary (Articles 42 and 43)

4) The opening of bank secrets due to the interests of banking activities (Article 44)

6) The opening of bank secrecy at the request of the account 
holder (Article 44A)

7) The opening of bank secrets relates to the obligation to report (Article 14 of Law No. 15 of 2002 on Money Laundering Crime)

c. Criminal acts related to bank supervision and coaching

Act Number 7 of 1992 concerning Banking Principles, as amended by Act Number 10 of 1998 concerning Amendment to Act Number 7 of 1992 concerning Banking, states that criminal acts which belong to the related types of criminal offenses with bank secrets, contained in Article 48 paragraph (1) and Article 48 paragraph (2), which stated that:

Paragraph (1): "A member of the board of commissioners, board of directors, or bank clerk who intentionally fails to provide the required information as referred to in Article 30 paragraph (1) and paragraph (2) and Article 34 paragraph (1) and paragraph (2), shall be subject to imprisonment of at least 2 (two) years and a maximum of 10 (ten) years and a fine of at least Rp. 5.000.000.000, - (five billion rupiah) and at most Rp. 100,000,000,000, - (one hundred billion rupiah)."

Paragraph (2): "Any member of the board of commissioners, board of directors, or bank clerk failing to provide the required information as referred to in Article 30 paragraph (1) and paragraph (2) and Article 34 paragraph (1) and paragraph (2) shall be threatened with imprisonment of at least 1 (one) year and a maximum of 2 (two) years and / or a fine of at least Rp. 1.000.000.000, - (one billion rupiah) and at most Rp. 2,000,000,000, - (two billion rupiah)."

d. Criminal acts related to the bank's business

In Act Number 7 of 1992 concerning Banking Principles, as amended by Act Number 10 of 1998 concerning Amendment to Act Number 7 of 1992 concerning Banking, it is stated that criminal acts which belong to the types of criminal offenses related to bank secrets, contained in:

Article 49 paragraph (1) letter a:

"A member of the board of commissioners, board of directors or employee of a bank who in any way makes or causes false records in the books or in the process of the report, as well as in documents or business activities, transactions or accounts of a bank."

Article 49 paragraph (1) letter b: 
"A member of the board of commissioners, board of directors, or bank clerk who deliberately eliminates or excludes or causes the nonrecording of bookkeeping, or in reports, nor in documents or reports of business activities, transaction reports or bank accounts."

Article 49 paragraph (1) letter c:

"A member of a board of commissioners, board of directors, or bank clerk who intentionally modifies, obscures, conceals, removes or omits any record keeping in the books or in 34 reports, nor in documents or reports of business activities, transactions or accounts of a bank, intentionally modify, obscure, eliminate, hide or damage the accounting records shall be punishable by imprisonment of at least 5 (five) years and a maximum of 15 (fifteen) years and a fine of at least Rp. 10,000,000,000.00 (ten billion rupiah) and at most Rp. 200,000,000,000.00 (two hundred billion rupiah)."

Article 49 paragraph (2) letter a:

"A member of the board of commissioners, board of directors or employee of a bank who solicits or receives, permits or agrees to receive any remuneration, commission, additional money, services, money or valuables, for his personal gain or for the benefit of his family, in order to obtain or attempt get a share another person in obtaining an advance deposit, bank guarantee or credit facility from the bank, or in order to purchase or discount by the bank on notes, promissory notes, checks and trade papers or other proof of liability, or in order to give consent to the person to withdraw funds exceeding the credit limit of the bank, shall be punished with imprisonment of at least 3 (three) years and a maximum of 8 (eight) years and a fine of at least Rp. 5.000.000.000,00 (five billion rupiah) and at most Rp. 100,000,000,000.00 (one hundred billion rupiah)."

According to the explanations of Article 49 paragraph (1) and paragraph (2) items a and b, the term bank clerk in the article has a different understanding. In the provision of Article 49 paragraph (1) and the provision of Article 49 paragraph (2) point a that is meant by bank employees are all officers and employees of the bank, whereas in Article 49 paragraph (2) point b referred to the bank officer is a bank official has authority and responsibility on matters relating to the business of the bank concerned. ${ }^{30}$

e. Criminal acts relating to attitudes and / or actions carried

30 Hermansyah, op.cit., p. 156 
out by management, employees, affiliated parties, and bank shareholders

In Act Number 7 of 1992 concerning Banking Principles, as amended by Act Number 10 of 1998 concerning Amendment to Act Number 7 of 1992 concerning Banking, it is stated that criminal acts which belong to the types of criminal offenses related to bank secrets, contained in:

Article 49 paragraph (2) letter b:

"A member of the board of commissioners, board of directors, or employee of a bank who by all means does not carry out the necessary measures to ensure compliance with the provisions of this law and the provisions of other laws applicable to the bank shall be punishable by imprisonment of at least 3 (three) years and maximum of 8 (eight) years and a fine of at least Rp. 5.000.000.000,00 (five billion rupiah) and at most Rp. 100,000,000,000.00 (one hundred billion rupiah)."

Article 50:

"An affiliated party who by all means does not carry out the necessary measures to ensure compliance with the provisions of this law and other laws applicable to the bank shall be punishable by imprisonment of at least 3 (three) years and the longest 8 (eight) years and a fine of at least Rp. 5.000.000.000,00 (five billion rupiah) and at most Rp. 100,000,000,000.00 (one hundred billion rupiah)."

\section{Article 50A:}

"Shareholders who deliberately instruct the board of commissioners, directors, or bank employees to commit or not to take action that causes the bank not to implement the necessary measures to ensure the bank's compliance with the provisions of this law and the provisions of other applicable laws and regulations for a bank, shall be punished with imprisonment of at least 7 (seven) years and a maximum of 15 (fifteen) years and a fine of at least Rp. 10,000,000,000.00 (ten billion rupiah) and at most Rp. 200,000,000,000.00 (one hundred billion rupiah),"

For Article 50A is the embodiment of the principle of piercing corporate veil. This principle is an exception to the provisions contained in Article 3 paragraph (1) of Law Number 40 of 2007 stating that the shareholder of the company is not personally liable for the commitments made on behalf of the company and is not liable for the loss of the company over its shares. 
In addition to being grouped into 5 ( five ) main groups as described above, the classification of criminal offenses in the banking sector can also be classified into criminal offenses in the form of crime and offense in the form of violations. ${ }^{31}$ The distinction between crime and offense is generally distinguished on the basis of quantitative distinctions (concerning the weight or lightness of criminal threats). The classification of such crimes has also been regulated in Act Number 7 of 1992 concerning Banking Principles, as amended by Act Number 10 of 1998 concerning Amendment to Act Number 7 of 1992 concerning Banking, namely in Article 51 paragraph (1) and Paragraph (2) which stated that: Criminal acts as referred to in Article 46, Article 47, Article 47A, Article 48 paragraph (1), Article 49, Article 50, and Article 50A are criminal. The criminal act as referred to in Article 48 paragraph (2) is a violation.

In addition to criminal sanctions, parties who commit criminal offenses in the banking sector will also be subject to additional sanctions, namely administrative sanctions. This is in accordance with the provisions contained in Article 52 of Act Number 7 of 1992 concerning Banking Principles, as amended by Act Number 10 of 1998 concerning Amendment to Act Number 7 of 1992 concerning Banking, which stated as following:

Paragraph (1): "Without prejudice to the criminal provisions referred to in Article 47, Article 47A, Article 48, Article 49, and Article 50A, Bank Indonesia may impose administrative sanctions to banks that do not fulfill their obligations as referred to in this law, or the Head of Bank Indonesia shall revoke the business license of the concerned bank."

Paragraph (2): "The administrative sanctions referred to in paragraph (1), among others are:

a. Money Fines;

b. Written reprimands;

c. Decrease in bank soundness;

31 Ibid., p. 151. 
d. Prohibition to participate in clearing activities;

e. Freezing of certain business activities, whether for certain branch offices or for banks as a whole;

f. Dismissal of the bank administrator and subsequently appoint and appoint a temporary replacement until the General Meeting of Shareholders or Meeting of Cooperative Members appoints a permanent replacement with the approval of Bank Indonesia;

g. Inclusion of members, managers, bank employees, shareholders in the list of disgraceful persons in banking.

Paragraph (3): "Further implementation of administrative sanctions shall be stipulated by Bank Indonesia."

\section{Banking Criminal Acts Outside the Banking Act}

a. Formulation of Banking Crime in Indonesian Criminal Code (KUHP)

Beside the Baking Act, banking crime also stipulated in some laws and regulations in Indonesia. The formulation of banking crime as regulated in the Criminal Code (KUHP), such as: (1) Crime of Counterfeiting, (2) Embezzlement, (3) Fraud, (4) Counterfeiting and Replacement of Credit Verband Collateral.

First, counterfeiting, jurisdictionally, the forger is involves the falsification of bank letters / certificates, authentic deeds and import export documents in various banking services activities. Therefore, the criminal act of counterfeiting can be classified into two types, namely: criminal act of forgery of bank letters / documents and documents as regulated in Article 263 of the Criminal Code and the offense of authentic deed and securities as regulated in Article 264 of the Criminal Code.

Second, embezzlement, that is clear that the Criminal Code has formulated in such a manner the criminal act of embezzlement whose conception can be related to the banking business activities in the depository institution of goods and securities in the safe deposit box, as well as the depositary for the interest of 
the other party. The criminal act of embezzlement is regulated in Article 374 and Article 415 of the Criminal Code.

Third, the provisions regulating fraud are contained in the formulation of Article 378 of the Criminal Code, where the conceptual criminal act of fraud can be imposed on criminal acts relating to transactions in the banking sector, for the purpose of obtaining profits which cause material losses on the other.

Forth, Counterfeiting and Replacement of Credit Verband Collateral, in which that this type of crime is common in the field of bank credit, where the object of credit verband is not entitled and / or collateralized several times without the knowledge of other parties (banks and persons owning or having material rights). The formulation of this criminal offense is contained in the provisions of Article 385 of the Criminal Code.

Fifth, Unfair competition, in which that increasing competition between banks today, does not rule out the existence of unhealthy competition (cheating) between competitior, both to benefit themselves and others (his company). One form of fraudulent competition among them is the spread of rumors (news lie) about banks that lose clearing. Against such crime shall be subject to the provisions of Article 382 bis and Article 390 of the Criminal Code.

b. The Formulation of Banking Crime on Anti-Corruption Eradication Act

Referring to the provisions of Law Number 31 of 1999 regarding Corruption Eradication, ${ }^{32}$ as amended by Law No. 20 of $2011,^{33}$ it can be classified as a banking crime whose regulation can apply the provisions of corruption law, as follows:

1) Criminal acts enrich themselves/others/legal entities in violation of the law, provided for in Article 2 paragraph (1);

2) The offense of abuse of authority, opportunity or means available to him or her due to position or position, is governed

32 State Gazette of Republic Indonesia Number 140 of 1999 Additional State Gazette Number 3874.

33 Additional State Gazette Number 4150 
by Article 3;

3) The criminal act of embezzlement as referred to in Article 415 of the Criminal Code shall be stipulated in the provisions of Article 8;

4) The criminal act of counterfeiting in Article 416 of the Criminal Code, set forth in the provisions of Article 10;

5) The criminal act of bribery as intended in Article 418 shall be regulated in Article 11;

6) The criminal act as referred to in Article 419, 420, 423, 425 of the Criminal Code, is regulated in Article 12.

Based on the description of banking crime whose regulation can apply the provisions in the law to eradicate corruption as mentioned above, it should be mentioned that not all banking crimes can be applied absolutely into the provisions of the law to eradicate corruption. In order to be ensnared under this law, a banking crime must comply with the elements to the detriment of state finances or the economy of the country.

\section{Law Enforcement on Baking Crime Involving Insiders}

\section{Handling of Banking Crime in Indonesia: Cooperation Between Agencies}

Bank of Indonesia in the law enforcement of banking crime in Indonesia has been initiated a cooperation with the Police of the Republic of Indonesia and the Attorney General of the Republic of Indonesia. The effort is made by Bank Indonesia to make the banking industry an increasingly healthy industry and can be trusted by the community. In addition, these efforts are also in line with the implementation of the Indonesian Banking Architecture (Arsitektur Perbankan Indonesia, API), especially in the 3rd Pillar, which is to create a strong and highly competitive banking industry with resilience to face risks. ${ }^{34}$

34 Arsitektur Perbankan Indonesia (API), Bank Indonesia official website, retrieved from http://www.bi.go.id/id/perbankan/arsitektur/Contents/ Default.aspx 
Concerning the authority of Bank Indonesia as a complete banking authority is contained in Act Number 23 of 1999 concerning Bank Indonesia ${ }^{35}$ as amended by Act Number 3 of 2004 (the BI Law $)^{36}$ and Law Number 7 of 1992 as amended by Law Number 10 of 1998 concerning Banking.

In relation to the imposition of sanctions, Bank Indonesia as the banking authority through supervision and guidance mechanism can only resolve administrative actions and only authorized to impose administrative sanctions on a bank that is proven to conduct business activities that deviate from the prevailing provisions while deviations that have indications of criminal offenses, the process of imposition of sanctions is left to law enforcement in accordance with applicable laws and regulations.

Supervision and law enforcement itself is an inseparable two components in a system of rule of law. There will be no law enforcement in the absence of a supervisory system and there will be no rule of law in the absence of adequate law enforcement. If this is analogous to the banking system, oversight and law enforcement can play a role in optimizing the banking function in order to create a sound banking system, both in the banking system as well as individually, and capable of maintaining the interests of the community well, developing fairly and beneficial to the economy national.

With regard to the limitation of such authority, in order to enforce the law in the banking industry and secure public funds and the existing state assets of banks, Bank Indonesia deems it necessary to coordinate with law enforcement officers in the handling of criminal offenses in the banking sector. Through a Joint Decree (SKB) between the Chief of Police of the Republic of Indonesia, the Attorney General of the Republic of Indonesia, and the Governor of Bank Indonesia, issued on 6 November 1997 and renewed on December 20, $2004,{ }^{37}$ the three agencies agreed to cooperate in the handling of al-

35 State Gazette Number 66 of 1999 Additional State Gazette Number 3843.

36 State Gazette Number 7 of 2004

37 Titi Kustini, 2012, "Nota Kesepahaman Bank Indonesia, Kepolisian, dan Kejaksaan Sebagai Bentuk Koordinasi Penanganan Tindak Pidana Per- 
leged criminal offenses in the banking sector. Through this partnership, it is expected that every banking case can be settled smoothly, quickly and optimally.

In order to support the implementation of LCS and to carry out repressive actions against violations and irregularities and noncompliance with prevailing regulations, particularly those containing elements of criminal offenses in the banking sector, Bank Indonesia established a special unit to handle allegations of criminal offenses in the banking sector, namely Directorate of Investigation and Banking Mediation DIMP). ${ }^{38}$ The formation of DIMP is expected to result in an announcement effect on the banking world that law enforcement in banking activities is still carried out and enforced and all forms of deviation will bring legal consequences for the perpetrators.

In its implementation, necessary steps to accelerate and optimize the handling of alleged criminal acts in the banking sector in 2007 made the Technical Guidelines of the LCS signed by the Deputy Attorney General for Special Crimes, Junior Attorney General for Public Crime, Head of Criminal Investigation Agency of POLRI and Deputy Governor of BI.

In addition to cooperating with the Attorney and Police, Bank Indonesia also cooperates with the Corruption Eradication Commission (KPK) on the handling of allegations of corruption in the bank, and the Financial Transaction Reports and Analysis Center (PPATK) related to the prevention and eradication of money laundering, as well as with Bapepam LK (now OJK) related to the handling of bank problems whose products/services are related to the capital market.

\section{Prevention of Banking Crime}

a. Bank Compliance Function

The role of internal control is very important to prevent

bankan”, Buletin Hukum Perbankan dan Kebanksentralan Vol. 10 Number 1, January-April 2012, Jakarta, Departemen Hukum Bank Indonesia, p. 1-12.

38 Media Perbankan, Bank Indonesia official website, http://www.bi.go.id/ $\mathrm{id} /$ iek/mediasi-perbankan/tata-cara/Contents/Default.aspx, accssed 28 April 2018 
the occurrence of banking crimes. One monitoring tool is carried out by the compliance work unit. The bank's compliance function is an independent function that identifies, assesses, advises, monitors and reports bank compliance risks such as the risk of legal sanctions, financial losses or loss of reputation that banks may suffer from bank failures in compliance with applicable laws, codes and banking practices. In October 2013, the Basel Committee on Banking Supervision, Bank for International Settlement (BIS) issued a consultative document on compliance function at the bank containing 10 (ten) principles that must be owned for the function of compliance in a bank run effectively. ${ }^{39}$ These ten principles are: First, the board is responsible for monitoring the bank's risk management. The Board must approve the bank's compliance policy, including official documents on the formation of compliance function. At a minimum, once a year, the board shall review the bank's compliance policy and its implementation to assess the extent to which the bank has effectively managed compliance risks. Bank unity policies will not be effective if there is no clear commitment from the board to increase the values of honesty and integrity in the company. Complying with laws and standards is an important tool for achieving goals.

Second, senior management of the bank is responsible for drafting a unity policy and ensuring the observation and reporting of its implementation to the board. Senior management is also responsible for assessing whether (compliance policy) is adequate. There should be a written compliance policy that identifies the key compliance risk issues facing the bank and explains how the bank intends to control it. The policy should contain the basic principles that all staff (including senior management) must follow. For clarity and transparency it is necessary to differentiate

39 Basel Committee on Banking Supervision, 2014, Consultative Document: Guidelines Corporate Governance Principle for Banks, Bank for International Settlement, ISBN 978-92-9131-905-3 (online), http://www.bis.org/ publ/bcbs294.htm 
between the standards that apply to all staff and the standards for particular staff. The senior duty of management is to ensure that compliance policies are carried out with full responsibility and corrective and disciplinary actions are exercised in the event of a breach.

Third, senior management of the bank is responsible for establishing a permanent and effective compliance function as part of the bank's compliance policy. Senior management must take the necessary steps to ensure the bank can rely on a permanent and effective compliance function. Fourth, the bank compliance function must have a formal status in the bank. This can be done by posting in the articles of association describing the position, authority and independence of the compliance function.

Fifth, the bank's compliance function should be independent. The compliance function should be capable of performing its own initiative in all departments in the bank where there is a risk of compliance. The compliance function should be free to report to senior management and management on any suspicions and possible violations found in the investigation without fear of reprisals and inconvenience from management and other staff. The functions of a tribunal shall have the right of its own initiative in communicating with other staff and having access to any records or documents required in carrying out its duties. Independence also requires that the compliance function be given sufficient resources to be able to perform the task effectively. Compensation budgets and schemes for compliance staff should be consistent with the objectives of the compliance function so that it does not have to depend on the financial performance of various other business lines.

Sixth, the role of compliance function is to identify, assess and monitor compliance risks facing the bank and provide advice and reports to senior management and management regarding such risks. Seventh, the leadership of the compliance function is responsible for day to day management of compliance function activities. Eighth, the staff performing the compliance responsibilities 
must have the qualifications, experience and professionalism and personal qualities in order to perform the task effectively. Ninth, compliance functions with banks that have overseas business activities should be structured so that compliance issues are set out in a comprehensive compliance policy framework. Lastly, the scope and extent of compliance function activities shall be periodically reviewed by the internal audit.

b. KYC (Know Your Customer)

According to Bank Indonesia Regulation, ${ }^{40}$ is a principle of Know Your Customer (KYC) principle applied is the bank to find out the identity of customers, monitor customer transaction activity including the reporting of suspicious transactions. In addition, this principle is intended to prevent the use of banks as a means of money laundering by bank customers. Some things that are required for banks in applying the KYC principles are as follows:

1. Establish policies on customer acceptance, customer identification procedures, and monitoring procedures for customer accounts and transactions, as well as risk management procedures related to the application of KYC.

2. Reporting suspicious transactions to BI no later than 7 working days after being believed by the bank.

3. Applies the applicable KYC principles in a country to overseas branch offices, as long as the KYC standards are the same or more stringent than those set forth in the PBI, and where local regulations are looser shall be applied by the KYC PBI. In the event that the application of the KYC PBI results in violation of local state provisions, it shall be reported to its head office and BI.

4. Banks are required to apply the principle of KYC and updating the data base of existing customers at the latest on

40 Bank of Indonesia Regulation No.3/10/PBI/2001 concerning Implementation of Know Your Customer Principles dated June 18, 2001 (Peraturan Bank Indonesia No.3/10/PBI/2001 tentang Penerapan Prinsip Mengenal Nasabah (Know Your Customer Principles) tanggal 18 Juni 2001) 
June 13, 2002.

5. Banks are required to implement training programs for bank employees on the KYC principle not later than 13 February 2002.

6. Implementation of information systems that can identify, analyze, monitor and provide a report on the characteristics transaction conducted by bank customers must be ready not later - latest on June 13, 2002.

As for sanctions if the bank does not report changes to the Code of Conduct Know Your Customer Principles no later than 7 working days since the stipulation of the change and not report to BI suspicious transactions that occurred in the bank concerned no later than 7 working days since the transaction is known by the bank, shall be liable to sanctions in the form of a financial penalty of Rp.1,000,000.00/ day of delay and a maximum of Rp 30,000,000.00

While sanctions if the bank does not carry out other obligations is by imposition of administrative sanctions as referred to in Article 52 paragraph (2) letter b, c, e, f or g Act No.7 of 1992 concerning Banking as amended by Act No .10 in 1998 which is in the form of:

7. Written reprimands;

8. Decrease in bank soundness;

9. Freezing of certain business activities, whether for certain branch offices or for banks as a whole;

10. Dismissal of the bank administrator and subsequently appoint and appoint a temporary replacement until the General Meeting of Shareholders or Meeting of Cooperative Members appoints a permanent replacement with the approval of $\mathrm{BI}$;

11. Inclusion of members of the board, bank employees, shareholders in the list of persons deplorable in the field of Banking.

In addition to the above administrative sanctions, against members of the Board of Commissioners, Board of Directors or bank employees who intentionally do not implement the neces- 
sary measures to ensure compliance with the provisions of the banking laws and other laws applicable to banks (including PBI KYC), threatened with imprisonment of at least 3 years and a maximum of 8 years and a minimum fine of Rp. 5 billion and maximum Rp.100 billion (Article 49 paragraph (2) letter b Act No.7 of 1992 concerning Banking as amended by Act No.10 of 1998).

There are several obstacles experienced in the reporting of suspicious transaction report (STR) from banks either from internal (bank) or from external (community), among others obstacles faced by bank in implementing KYC principle, in the form of $^{41}$ :

1) Afraid of losing customers. Banks are worried about losing customers when applying fully KYC principles to both existing customers and new customers. This is because the banks do not simultaneously apply KYC principles to customers. This condition provides an opportunity for customers to refuse to provide information and transfer their funds to banks that have not applied KYC principles.

2) Business scale of the bank. For large-scale banks (for example having more than 21,000 employees with 800 branches and 8 million customers across Indonesia) tend to be more difficult to apply full KYC principles, such as customer profile data collection, employee training, and information system procurement for that it takes a long time, great cost and sufficient expertise.

3) Bank distrust of law enforcement. Although Law Number 8 Year 2010 concerning Prevention and Eradication of Money Laundering Criminal Act (Money Laundering Act) ${ }^{42}$ has provided certainty of security guarantee for banks in the

41 Zulkarnain Sitompul, 2004, “Tindak Pidana Perbankan dan Pencucian Uang (Money Laundering)”, Reformasi Hukum Vol. VII No. 2 July-December, pp. 15-16.

42 State Gazette Number 122 of 2010, Additional State Gazette Number 5164. 
implementation of report submission as stated in Article 15, and Article 40 - 42 of Law on TPPU but the bank still doubt its implementation especially to law enforcement apparatus.

Besides, the lack of public attention to the provisions of $\mathrm{KYC}$ is the main obstacle faced by all banks in applying the KYC principles. This is because ${ }^{43}$ :

a. Completion of the KYC form troubles the customer and is overreacted (such as filling the position, mother's name, hobbies, loans from other banks) and uncomfortable;

b. Fear of financial secrets known by others such as taxation;

c. Do not feel the benefits of charging KYC and assume the bank is too inquisitive about customers' internal problems.

In addition, the impacts faced by banks when applying KYC principles include ${ }^{44}$ :

a. The Customer refuses to fill out the KYC form that has been submitted and will withdraw the funds if still required to fill out;

b. Customers tend to be dishonest in filling income data and hard to find;

c. Depositors object to paychecks because they do not think of borrowers.

Based on the above matter, the preventive effort that is carried out besides reinforcing the bank compliance commitments (compliance) also apply the principle of know your customer becomes very important in prevention of banking crime in Indonesia. Therefore, the insider's involvement in the bank case in many cases becomes the focus of its own, not only for law enforcement, but also its prevention efforts.

Banking crime involves public funds deposited in the bank, therefore banking Crime is detrimental to the interests of various parties, both the bank itself as a business entity as well as the depositors of funds, banking system, banking authority the government and the wider community, requiring thorough han-

43 Zulkarnain Sitompul, loc.cit

44 Ibid. 
dling.

The role of strategic banking and bank characteristics as, a trust institution, then anything that disrupts banking activities such as Banking Crime requires good handling. Given that Bank Indonesia does not have the authority to conduct investigations, the handling of alleged Banking Crime requires coordination with other institutions, one of which is coordination between Bank Indonesia and law enforcement officials.

\section{Conclusion}

Based on the description of the discussion in this research report, related to law enforcement on banking crime involving insider in Indonesia, can be drawn some conclusions, that, legal arrangements concerning banking crime are regulated in Law Number 10 Year 1998 concerning Amendment to Act Number 7 of 1992 concerning Banking. In addition, banking criminal arrangements can also be found in the Criminal Code (KUHP) Article 263 relating to counterfeiting, Article 374 and Article 415 relating to embezzlement, Article 378 relating to fraud, Article 385 relating to counterfeiting and reproduction of credit verband collateral, Article 382 bis and Article 390 related to cheating. Law Number 20 of 2011 jo Law Number 31 of 1999 on Eradication of Corruption can also be used as legal basis in handling banking crime cases, but on condition that the activities fulfill the element of detrimental to state finance or national economy.

Banking crimes committed by insiders due to weak internal supervision and the implementation of loose standards, among others in the form of non- check and recheck of transaction handling; lack of supervisory supervision of subordinates; less stringent internal control system to priority banking operational activities, which in terms of privacy has the advantage of service as well as having a vulnerability knot susceptibility by bank officials. Related to the handling of banking crime cases involving insiders, Bank Indonesia participates in law enforcement in the form of investigation and / or forensic examination of bank crime that occurs in a bank. The results 
of these investigations are reported to law enforcement in accordance with applicable Criminal Procedure Code. In addition, in the case of law enforcement, Bank Indonesia cooperates with the Police and Attorney General's Office through a Joint Decree, which then forms a memorandum of understanding between Bank Indonesia, the Police and the Supreme Court of the Republic of Indonesia, through some Memorandum of Understanding agreements concerning the Coordination of Handling of Banking Crime. In relation to prevention of banking crime, the existence of internal supervisory function through the compliance work unit in charge of ensuring bank compliance function has been carried out in accordance with and as regulated in the 10 principles of bank compliance with the Basel Committee on Banking Supervision consultative document, Bank for International Settlement. In addition Know Your Customer (KYC) principle is also required for each bank to prevent suspicious transactions.

\section{Bibliography}

Anti-Corruption Clearing House KPK, "Modus Korupsi Sektor Perbankan," http: / / acch.kpk.go.id/ documents / 10157/ 27925 / Modus_Korupsi_Sektor_Perbankan.pdf

Anwar, H.A.K.Moch, 1986, Tindak Pidana di Bidang Perbankan, Alumni, Bandung

Arrasjid, Chainur, 2011, Hukum Pidana Perbankan, Sinar Grafika, Jakarta.

Arsitektur Perbankan Indonesia (API), Bank Indonesia official website, retrieved from http://www.bi.go.id/id/perbankan/arsitektur/Contents / Default.aspx, access on January 2017

Bank Indonesia, www.bi.go.id, access on January 2017

Bank of Indonesia Regulation No.3 / 10 / PBI / 2001 concerning Implementation of Know Your Customer Principles dated June 18, 2001 (Peraturan Bank Indonesia No.3/10/PBI/2001 tentang Penerapan Prinsip Mengenal Nasabah (Know Your Customer Principles) tanggal 18 Juni 2001)

Bank of Indonesia Regulation No.3/23/PBI/2001 concerning 
Amendment to Bank Indonesia Regulation No.3/10/PBI/2001 on Implementation of Know Your Customer Principles dated 13 December 2001 (Peraturan Bank Indonesia No.3/23/PBI/2001 tentang Perubahan atas Peraturan Bank Indonesia No.3/10/ PBI / 2001 tentang Penerapan Prinsip Mengenal Nasabah (Know Your Customer Principles) tanggal 13 Desember 2001)

Basel Committee on Banking Supervision, 2014, "Consultative Document: Guidelines Corporate Governance Principle for Banks”, Bank for International Settlement, ISBN 978-92-9131-905-3 (online), http://www.bis.org/publ/bcbs294.htm, access on January 2017

BPHN, 1992, "Masalah-Masalah Hukum Kejahatan Perbankan”, Research Report, BPHN Departemen Kehakiman, Jakarta.

Decree of the Minister of Finance No. 792 of 1990 (Surat Keputusan (SK) Menteri Keuangan RI Nomor 792 Tahun 1990)

Denzin, Norman K. dan Lincoln, Yvonna S. (Eds), 2009, Handbook of Qualitative Research, Sage Publication, California USA, Translated and Published on Bahasa by Pusataka Pelajar, Yogyakarta.

Dion Bistara \& Grace Dwitya Amianti, 2012, "Indonesia Still Struggling with Electronic Fraud: Bank Indonesia”, Online News, edition 6 July 2012, retrieved from http:/ / www.thejakartaglobe. $\mathrm{com} /$ archive / indonesia-still-struggling-with-electronic-fraudbi/, access on January 2017

Ferizal, 2001, "Kebijakan Hukum Pidana dalam Penanggulangan Tindak Pidana Bidang Perbankan”, Thesis, Master of Laws, Universitas Diponegoro, Semarang.

Hermansyah, 2006, Hukum Perbankan Indonesia, Kencana, Jakarta.

Kustini, Titi, 2012, "Nota Kesepahaman Bank Indonesia, Kepolisian, dan Kejaksaan Sebagai Bentuk Koordinasi Penanganan Tindak Pidana Perbankan”, Buletin Hukum Perbankan dan Kebanksentralan, Vol. 10 Number 1, January-April 2012, Legal Department of Bank Indonesia, Jakarta.

Lash, Nicholas, A., 1987, Banking Law and Regulation: An Economic Perspective, Prentice Hall, USA.

Law No, 23 of 1999 concerning Bank of Indonesia (Undang-Undang 
Nomor 23 Tahun 1999 tentang Bank Indonesia)

Law No. 31 of 1999 concerning Corruption Eradication jo Law Number 20 Year 2001 regarding Amendment to Law Number 31 of 1999 concerning the Eradication of Corruption (UndangUndang Nomor 31 Tahun 1999 tentang Pemberantasan Tindak Pidana Korupsi jo Undang-Undang Nomor 20 Tahun 2001 tentang Perubahan Atas Undang-Undang Nomor 31 Tahun 1999 tentang Pemberantasan Tindak Pidana Korupsi)

Law No. 7 of 1992 concerning Banking Principles, as amended by Act Number 10 of 1998 concerning Amendment to Act Number 7 of 1992 concerning Banking (Undang-Undang Nomor 7 Tahun 1992 tentang Pokok-Pokok Perbankan, sebagaimana telah diubah dengan Undang-Undang Nomor 10 Tahun 1998 tentang Perubahan Atas Undang-Undang Nomor 7 Tahun 1992 tentang Perbankan)

Mamudji, Sri, et.al., 2005, Metode Penelitian dan Penulisan Hukum, Badan Penerbit Fakultas Hukum Universitas Indonesia, Jakarta.

Media Perbankan Bank Indonesia, retrieved from http: / / www.bi.go. $\mathrm{id} / \mathrm{id} / \mathrm{iek} /$ mediasi-perbankan/tata-cara/Contents / Default. aspx, access on January 2017

Memorandum of Understanding between Bank Indonesia, the Police and the Implementation of the Republic of Indonesia No.13 / 104 / KEP.GBI / 2011, No. B / 31/XII/2011, No.Kep-261 / A / JA / 12/2011 on Coordination of Handling Banking Crime (SK Handling Tipibank) (Nota Kesepahaman antara Bank Indonesia, Kepolisian, dan Kejaksanaan Republik Indonesia No.13/104/ KEP.GBI /2011, No.B/31/XII/2011, No.Kep-261 / A/JA/12/ 2011 tentang Koordinasi Penanganan Tindak Pidana Perbankan (NK Penanganan Tipibank)

Nina Dwiantika, "Inilah 9 Kasus Kejahatan Perbankan”, Online News, edition 3 May 2011, http://bisniskeuangan.kompas.com/ $\mathrm{read} / 2011$ / 05 / 03 / 09441743 / Inilah.9.Kasus.Kejahatan.Perbankan access on January 2017

, "2013, BI Investigasi 62 Kasus Tindak Pidana Bank", Online News, edition 11 March 2014, retrieved from http:/ / keuangan. 
kontan.co.id/news/2013-bi-investigasi-62-kasus-tindak-pidanabank, access on January 2017

Pardede, Marulak, 1995, Hukum Pidana Bank, Pustaka Sinar Harapan, Jakarta.

Setiadi, Edi, 2010, Hukum Pidana Ekonomi, Graha Ilmu, Yogyakarta.

Sholehuddin, M., 1997, Tindak Pidana Perbankan, PT Raja Grafindo Persada, Jakarta.

Sitompul, Zulkarnain, 2004, "Tindak Pidana Perbankan dan Pencucian Uang (Money Laundering)", Reformasi Hukum, Vol. VII No. 2 July-December 2004.

Statement of Financial Accounting Standards (PSAK) No. 31 of the Indonesian Institute of Accountants, 1994 (Pernyataan Standar Akuntansi Keuangan (PSAK) Nomor 31 Ikatan Akuntan Indonesia, 1994)

Suhardi, Gunarto, 2003, Usaha Pembankan dalam Perspektif Hukum, Kanisius, Yogyakarta.

Sutedi, Adrian, 2007, Hukum Perbankan: Suatu Tinjauan Pencucian Uang, Merger, Likuidadi, dan Kepailitan, Sinar Grafika, Jakarta.

Triantono, 2013, "Konsep Kepatuhan (Compliance) dalam Sistem Pengawasan Perbankan di Indonesia", Thesis, Master of Laws, Universitas Gadjah Mada, Yogyakarta.

Wiji Nurhayat, "Ini Arti Penting Perbankan di Indonesia Bagi Pemerintah”, Online News, edition 6 January 2014, Online News, retrieved from http: / / finance.detik.com/ read/2014/01/06/11 0215/2459047 / 5 / ini-arti-penting-perbankan-di-indonesia-bagipemerintah, access on January 2017 